\title{
Hydroxypyridinecarboxylic acid derivatives influencing metal ion levels in the brain: Equilibrium complexation studies with $\mathrm{Cu}(\mathrm{II})$ and $\mathrm{Zn}(\mathrm{II})$
}

\author{
Éva Sija ${ }^{\mathrm{a}}$, Nóra Veronika Nagy ${ }^{\mathrm{b}}$, Valentina Gandin ${ }^{\mathrm{c}}$, Christine Marzano ${ }^{\mathrm{c}}$, Tamás Jakusch ${ }^{\mathrm{d}}$, \\ Annalisa Dean ${ }^{\mathrm{e}}$, Valerio B. Di Marco ${ }^{\mathrm{e}, *}$, Tamás Kiss ${ }^{\mathrm{a}, \mathrm{d}, *}$ \\ ${ }^{a}$ HAS-USZ Bioinorganic Chemistry Research Group, Dóm têr 7, H-6720 Szeged, Hungary \\ ${ }^{b}$ Institute of Molecular Pharmacology, Research Centre for Natural Sciences, HAS Pusztaszeri út 59-67, H-1025 Budapest, Hungary \\ ${ }^{c}$ Department of Pharmaceutical Sciences, University of Padova, Via Marzolo 5, 35131 Padova, Italy \\ ${ }^{\mathrm{a}}$ Department of Inorganic and Analytical Chemistry, University of Szeged, Dóm têr 7, H-6720 Szeged, Hungary \\ 'Department of Chemical Sciences, University of Padova, via Marzolo 1, 35131 Padova, Italy
}

\section{A R T I C L E I N F O}

Article history:

Received 2 July 2013

Accepted 29 September 2013

Available online 14 October 2013

\section{Keywords:}

$\mathrm{Cu}(\mathrm{II})$ and $\mathrm{Zn}(\mathrm{II})$ complex

Carboxylate ligands

Potentiometry

MTT-test

Chelation therapy

Neurodegenerative diseases

\begin{abstract}
A B S T R A C T
The metal ion chelators 4-hydroxy-5-methyl-3-pyridinecarboxylic acid (DQ5) and 1,5-dimethyl-4hydroxy-3-pyridinecarboxylic acid (DQ715) and $\mathrm{Cu}(\mathrm{II})$ and $\mathrm{Zn}(\mathrm{II})$ were investigated with the aim to restore the homeostasis of the brain $\mathrm{Cu}(\mathrm{II})$ and $\mathrm{Zn}(\mathrm{II})$ in neurodegenerative diseases. The proton dissociation constants of the ligands, the stability constants, and the coordination modes of the metal complexes formed were determined by pH-potentiometric, and spectral (UV-Vis and EPR or ${ }^{1} \mathrm{H} N M R$ ) methods. The results show that in slightly acidic and neutral $\mathrm{pH}$ range mono and bis complexes are formed through bidentate coordination of the ligands. The biological MTT-test reveals that the DQ715 ligand is able to lower the cytotoxic effect of $\mathrm{Cu}$ (II) in human embryonic kidney HEK-293 cells. Our studies revealed, however, that none of the chelators were efficient enough to withdraw these metal ions from the amyloid aggregates.
\end{abstract}

(C) 2013 Elsevier Ltd. All rights reserved.

\section{Introduction}

Balanced homeostasis of metal ions is critical for the normal function of the brain and is maintained within strict limits [1]. Disharmony in metal ion homeostasis, especially that of iron and copper will cause oxidative stress by increasing the formation of reactive oxygen species (ROS) as superoxide ion, hydrogen peroxide, and hydroxyl radical, and thus damage many biomolecules in the cells resulting in various neurodegenerative disorders [2].

It has been demonstrated that the increased brain $\mathrm{Cu}$ (II), $\mathrm{Fe}$ (III) and also $\mathrm{Zn}$ (II) concentration in dyshomeostasis of these metal ions influences the oligomerisation of $\beta$-amyloids in the Alzheimer'brain [3]. The interactions of these metal ions with amyloid precursor (APP) or amyloid $\beta$-peptide (A $\beta$ ) can produce neurotoxic $\mathrm{H}_{2} \mathrm{O}_{2}$. Then the reduced metal ions reacting with hydrogenperoxide will generate the extremely reactive hydroxyl radicals from hydrogen peroxide in $\mathrm{M}(\mathrm{red})+\mathrm{H}_{2} \mathrm{O}_{2} \rightarrow \mathrm{M}(\mathrm{ox})+\mathrm{OH}^{-}+\mathrm{OH}^{-}$reaction leading to oxidative stress in brain [4-6]. Some selective ligands for $\mathrm{Cu}$ (II) have been proposed as chelating agents for the therapy of

\footnotetext{
* Corresponding authors. Address: Department of Inorganic and Analytical Chemistry, University of Szeged, Dóm tér 7. H-6720 Szeged, Hungary. Tel.: +36 62 544337 (T. Kiss).

E-mail addresses: valerio.dimarco@unipd.it (V.B. Di Marco), tkiss@chem.u-szeged. hu (T. Kiss).
}

AD. The first was clioquinol (CQ), which could chemically solubilize $A \beta$ deposits in $A D$ [7] likely through the interaction with copper. Faller and coworkers suggested that a chelator with a conditional dissociation constant $\left(K_{\mathrm{D}}\right)$ of $10 \mathrm{pM}$ (up to $100 \mathrm{nM}$ range) for $\mathrm{Cu}(\mathrm{II})$ should be sufficient to retrieve copper completely from amyloid deposits [8]. Other results show that an $\alpha \mathrm{B}$-crystallin chaperon peptide prevents $\mathrm{Cu}(\mathrm{II})$-induced aggregation of $A \beta_{1-40}$ due to selective $\mathrm{Cu}(\mathrm{II})$ binding ability in addition to preventing the amyloid fibril formation of $A \beta$ peptides [9]. The dissociation constant $\left(K_{D}\right)$ for $\mathrm{Cu}$ (II) interaction with the chaperon peptide is in the $\mu \mathrm{M}$ range $[9,10]$.

The role of $\mathrm{Zn}$ this inert trace element is much less clear in the neurodegenerative processes. Reported $\mathrm{Zn}$ (II) affinity for $A \beta$ is significantly weaker than, that for $\mathrm{Cu}(\mathrm{II})$, values of dissociation constants ranging between 1 and $20 \mu \mathrm{M}$ [9]. However, the amyloid aggregates contain relatively high concentration (mM) of zinc [11]. Several attempts were made to obtain efficient chelators with moderate affinity towards the metal ions such as $\mathrm{Cu}$ (II), $\mathrm{Zn}$ (II) or $\mathrm{Fe}$ (III) that participate in amyloid aggregation, in order to prevent the formation of plaques [12-14].

In previous papers [15-20] we reported the evaluation of several hydroxypyridinecarboxylic acid derivatives (HPCs) as possible chelating agents for Fe(III) and Al(III). To this aim, the Fe(III) and $\mathrm{Al}(\mathrm{III})$ complexes formed with selected HPCs were studied. Now 
we extended these studies also to $\mathrm{Cu}$ (II) and $\mathrm{Zn}$ (II). On one hand, it is well known that any $\mathrm{Fe}$ (III) and $\mathrm{Al}(\mathrm{III})$ chelator can complex essential metal ions too in a chelation therapy regiment, thus causing toxic side effects due to metal ion deficiency. For example, zinc deficiency problems are sometimes experienced in the deferiprone therapy $[21,22]$. The evaluation of the complexation strength of HPCs towards $\mathrm{Cu}(\mathrm{II})$ and $\mathrm{Zn}$ (II) can allow to predict the extent of essential metal ion removal during the $\mathrm{Fe}(\mathrm{III})$ and $\mathrm{Al}(\mathrm{III})$ chelation therapy. On the other hand, the very low cytotoxicity of HPCs, and according to the Lipinski's rule their low molecular mass, the reasonable lipophilicity (which can allow the oral activity and the easy blood brain barrier crossing) can represent important advantages also for the employment of HPCs in the AD therapy. Therefore, the evaluation of the complexation strength of the HPCs towards $\mathrm{Cu}$ (II) and $\mathrm{Zn}$ (II) can allow to predict if these ligands can remove copper and zinc from $A \beta$, i.e. if they represent good candidates also in the recovery of the disturbed brain metal ion homeostasis in $\mathrm{AD}$.

In the present paper we studied the $\mathrm{Cu}(\mathrm{II})$ and $\mathrm{Zn}$ (II) binding affinity of two HPCs derivatives: 4-hydroxy-5-methyl-3-pyridinecarboxylic acid (DQ5) and 1,5-dimethyl-4-hydroxy-3-pyridinecarboxylic acid (DQ715) (Scheme 1). Their coordination properties in aqueous solution were determined by means of $\mathrm{pH}-$ potentiometric titrations, UV-Vis and ${ }^{1} \mathrm{H}$ NMR or EPR measurements. The effects of DQ715 with $\mathrm{Cu}$ (II) chloride were evaluated on cell viability of a combined way in human embryonic kidney HEK-293 cells.

\section{Experimental}

\subsection{Chemicals}

DQ5 and DQ715 were synthesized as described in Ref [15]. Double-distilled Milli-Q water was used for sample preparations. The purity of the ligands was checked and the exact concentrations of the stock solutions prepared were determined by potentiometric titrations using the program SUPEROUAD for data evaluation [23]. The $\mathrm{pH}$-metric titrations were performed with $0.1 \mathrm{~mol} / \mathrm{dm}^{3} \mathrm{KOH}$ prepared from $\mathrm{KOH}$ (Merck). The base was standardised against $\mathrm{HCl}$ solutions prepared from $36 \% \mathrm{HCl}$ (Merck). $\mathrm{A} \mathrm{ZnCl}_{2}$ stock solution was made by dissolution of anhydrous $\mathrm{ZnCl}_{2}$ in a known amount of $\mathrm{HCl}$, and its concentration was determined by complexometry via ethylenediaminetetraacetate complexes, and gravimetrically via the oxinate. The $\mathrm{CuCl}_{2}$ ion stock solutions were prepared from $\mathrm{CuCl}_{2} \cdot 2 \mathrm{H}_{2} \mathrm{O}$ (Reanal) dissolved in doubly distilled water, and the concentration of the metal ion was determined gravimetrically via precipitation of the oxinate.

\section{2. pH-potentiometric studies}

The pH-metric measurements for determining stability constants of the proton and metal complexes of the ligands were carried out in aqueous solution at an ionic strength of $0.2 \mathrm{~mol} / \mathrm{dm}^{3} \mathrm{KCl}$ (Sigma Aldrich) at $25.0 \pm 0.1^{\circ} \mathrm{C}$. The titrations were performed
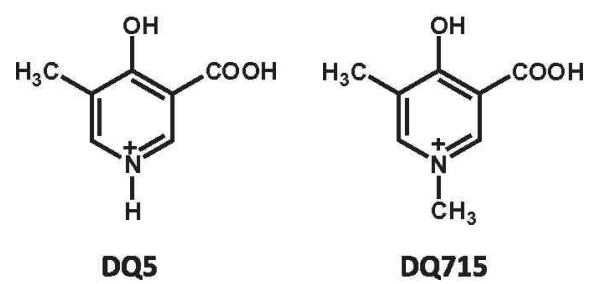

Scheme 1. 4-Hydroxy-5-methyl-3-pyridinecarboxylic acid (DQ5) and 1,5dimethyl-4-hydroxy-3-pyridinecarboxylic acid (DQ715) shown in their fully protonated forms $\left(\mathrm{H}_{3} \mathrm{~L}^{+}\right.$and $\mathrm{H}_{2} \mathrm{~L}^{+}$, respectively). with a carbonate-free $\mathrm{KOH}$ solution of know concentration (ca. $0.1 \mathrm{~mol} / \mathrm{dm}^{3}$ ). In order to keep the ionic strength constants $\mathrm{KCl}$ has been added to the $\mathrm{KOH}$ solution to set the $\mathrm{K}^{+}$concentration $0.2 \mathrm{~mol} / \mathrm{dm}^{3}$. The $\mathrm{HCl}$ concentration was determined by potentiometric titrations using the Gran's method [24]. An Orion 710A $\mathrm{pH}$-meter equipped with a Metrohm combined electrode (type 6.0234.1000) and a Metrohm 665 Dosimat burette was used for the pH-metric measurements. The electrode system was calibrated according to Irving et al. [25] (strong acid versus strong base; $\mathrm{HCl}$ versus $\mathrm{KOH}$ titration) and therefore the $\mathrm{pH}$-meter readings could be converted into hydrogen ion concentration. The water ionization constant, $\mathrm{p} K_{\mathrm{w}}$ calculated from strong acid-strong base titrations was $13.76 \pm 0.01$ under the conditions employed. The titrations were performed in the $\mathrm{pH}$ range $2-11$ or until precipitation occurred in the samples. The initial volume of the samples was $10 \mathrm{~cm}^{3}$ in case of DQ715 and $20 \mathrm{~cm}^{3}$ in case of DQ5 related titrations. The ligand concentration was in the range of $0.5 \times 10^{-3}$ $2 \times 10^{-3} \mathrm{~mol} / \mathrm{dm}^{3}$, and the metal ion to ligand ratios were $1: 1$, $1: 2$ and $1: 4$. The accepted fitting between the experimental and the calculated titration curves was always better than $0.01 \mathrm{~cm}^{3}$ and the uncertainties (3SD values) in the stability constants are given in parentheses in Table 1. The samples were in all cases deoxygenated by bubbling purified argon for $\mathrm{ca}$. $10 \mathrm{~min}$ before the measurements, and argon was also passed through the solutions during the titrations.

The protonation constants of the ligands were determined with the computer program SUPERQUAD [23]. PSEQUAD [26] was used to establish the stoichiometry of the complexes and to calculate their stability constants $\left(\log \beta\left(\mathrm{M}_{p} \mathrm{~L}_{q} \mathrm{H}_{r}\right) . \beta\left(\mathrm{M}_{p} \mathrm{~L}_{q} \mathrm{H}_{r}\right)\right.$ is defined for the general equilibrium reaction $p \mathrm{M}+q \mathrm{~L}+r \mathrm{H} \rightleftharpoons \mathrm{M}_{p} \mathrm{~L}_{q} \mathrm{H}_{r}$ as $\beta\left(\mathrm{M}_{p} \mathrm{~L}_{q-}\right.$ $\left.\mathrm{H}_{r}\right)=\left[\mathrm{M}_{p} \mathrm{~L}_{q} \mathrm{H}_{r}\right] /[\mathrm{M}]^{p}[\mathrm{~L}]^{q}[\mathrm{H}]^{r}$, where $\mathrm{M}$ denotes the metal ion, $\mathrm{L}$ is the completely deprotonated ligand molecule, and $p, q$ and $r$ are the number of metal, ligand, and proton atoms, respectively. According to the calibration protocol employed, the protonation and stability constants are concentration constants which refer to the given ionic strenght. The calculations were always made from the experimental titration data measured in the absence of any precipitate in the solution.

\subsection{Spectrophotometric measurements}

UV-Vis spectrophotometric measurements were performed in aqueous solution at $25.0 \pm 0.1^{\circ} \mathrm{C}$ on solutions containing the ligand (either DQ715 or DQ5) at a $8.0 \times 10^{-5} \mathrm{~mol} / \mathrm{dm}^{3}$ concentration, and the metal (either $\mathrm{Cu}(\mathrm{II})$ or $\mathrm{Zn}$ (II)) at the following metal to ligands ratios: $0: 1,1: 4,1: 2,1: 1$. The $\mathrm{pH}$ range was from 2 to 11 , and the ionic strength was $0.20 \mathrm{~mol} / \mathrm{dm}^{3}(\mathrm{KCl})$. The spectra were recorded under argon atmosphere. A Hewlett Packard 8452A diode array spectrophotometer was used to record the UV-Vis spectra in the interval $290-820 \mathrm{~nm}$. The pathlength was $1 \mathrm{~cm}$ using quartz cuvettes. Protonation and stability constants and the individual spectra of the species were calculated by the computer program PSEQUAD [26].

\section{4. ${ }^{1} \mathrm{H}$ NMR measurements}

${ }^{1} \mathrm{H}$ NMR studies were carried out on a Bruker Ultrashield 500 Plus instrument equipped with a $5 \mathrm{~mm}$ capillary NMR tube. In the NMR measurements the magnetic field was stabilised by locking with the ${ }^{2} \mathrm{D}$ signal of the solvent. The sample temperature was set to $25 \pm 1{ }^{\circ} \mathrm{C}$ during all data acquisitions. Chemical shifts are reported in $\mathrm{ppm}\left(\delta_{\mathrm{H}}\right)$ from 4,4-dimethyl-4-silapentane-1-sulfonic acid (DSS) as internal reference. The ${ }^{1} \mathrm{H}$ NMR measurements were performed with WATERGATE solvent suppression scheme. All samples were measured with the same experimental parameters, the same spectrometer and the same probe. The relaxation delay, the delay for binomial water suppression, and the number of scans, 
Table 1

$\mathrm{p} K_{\mathrm{a}}$ values of DQ5 and DQ715, and stability constants of $\mathrm{Cu}(\mathrm{II})$ and $\mathrm{Zn}(\mathrm{II})$ complexes at $298 \mathrm{~K}$ in aqueous $I=0.2 \mathrm{~mol} / \mathrm{dm}{ }^{3}(\mathrm{KCl})$.

\begin{tabular}{|c|c|c|c|c|c|c|}
\hline \multirow{3}{*}{ Species } & \multirow{2}{*}{\multicolumn{2}{|c|}{$\begin{array}{l}\mathrm{DQ5} \\
\mathrm{p} K_{\mathrm{a}} / \log \beta\end{array}$}} & \multicolumn{4}{|l|}{ DQ715 } \\
\hline & & & \multirow[t]{2}{*}{ Species } & \multicolumn{3}{|l|}{$\mathrm{p} K_{\mathrm{a}} / \log \beta$} \\
\hline & $\mathrm{pH}-\mathrm{pot}$ & UV-Vis & & $\mathrm{pH}-\mathrm{pot}$ & UV-Vis & ${ }^{1} \mathrm{H}$ NMR \\
\hline $\mathrm{H}_{3} \mathrm{~L}^{+}$ & & $0.23(6)^{*}$ & $\mathrm{H}_{2} \mathrm{~L}^{+}$ & $\sim 1$ & $0.40(1)^{*}$ & \\
\hline $\mathrm{H}_{2} \mathrm{~L}$ & $6.60(1)$ & $6.61(2)$ & $\mathrm{HL}$ & $6.64(1)$ & $6.63(1)$ & $6.66(1)$ \\
\hline \multirow[t]{2}{*}{$\mathrm{HL}^{-}$} & $>11$ & & & & & \\
\hline & $\mathrm{pH}$-pot & UV-Vis & & pH-pot & UV-Vis & EPR \\
\hline $\mathrm{Cu}(\mathrm{HL})^{+}$ & $6.24(1)$ & $6.39(3)$ & $\mathrm{CuL}^{+}$ & $6.27(1)$ & $6.41(2)$ & $6.47(2)$ \\
\hline $\mathrm{Cu}(\mathrm{HL})_{2}$ & $11.33(5)$ & $11.33(9)$ & $\mathrm{CuL}_{2}$ & $10.95(2)$ & $10.97(5)$ & $11.02(2)$ \\
\hline \multirow[t]{2}{*}{$K_{\mathrm{D}}$} & \multicolumn{2}{|c|}{$3.1 \times 10^{-7} \mathrm{~mol} / \mathrm{dm}^{3}$} & \multicolumn{3}{|c|}{$5.1 \times 10^{-7} \mathrm{~mol} / \mathrm{dm}^{3}$} & \\
\hline & \multicolumn{2}{|c|}{ pH-pot } & & \multicolumn{2}{|l|}{$\mathrm{pH}-\mathrm{pot}$} & ${ }^{1} \mathrm{H}$ NMR \\
\hline $\mathrm{Zn}(\mathrm{HL})^{+}$ & \multicolumn{2}{|l|}{$3.75(2)$} & $\mathrm{ZnL}^{+}$ & \multicolumn{2}{|l|}{$3.77(2)$} & $3.79(3)$ \\
\hline $\mathrm{Zn}(\mathrm{HL})_{2}$ & \multicolumn{2}{|l|}{$6.9(1)$} & $\mathrm{ZnL}_{2}$ & $7.06(3)$ & & $6.96(7)$ \\
\hline $\mathrm{K}_{\mathrm{D}}$ & \multicolumn{2}{|c|}{$7.5 \times 10^{-4} \mathrm{~mol} / \mathrm{dm}^{3}$} & \multicolumn{4}{|c|}{$8.2 \times 10^{-4} \mathrm{~mol} / \mathrm{dm}^{3}$} \\
\hline
\end{tabular}

$K_{\mathrm{D}}=[\mathrm{M}]_{\text {free }} \Sigma\left[\mathrm{H}_{\chi} \mathrm{L}\right] / \Sigma\left[\mathrm{M}_{p} \mathrm{H}_{q} \mathrm{~L}_{r}\right]$ computed at $\mathrm{pH} 7.4$ for $c_{\mathrm{M}}=2.5 \times 10^{-5} \mathrm{~mol} / \mathrm{dm}^{3}, c_{\mathrm{L}}=5.0 \times 10^{-5} \mathrm{~mol} / \mathrm{dm}^{3}$.

* Data are taken from Ref [15].

were $2 \mathrm{~s}, 150 \mu \mathrm{s}$, and 64, respectively. Spectra were collected for DQ5 and DQ715 ligands and for Zn(II)-DQ715 system in 90:10 $\mathrm{H}_{2} \mathrm{O} / \mathrm{D}_{2} \mathrm{O}$ mixtures at $1.1 \mathrm{mmol} / \mathrm{dm}^{3}$ (DQ5) and $2 \mathrm{mmol} / \mathrm{dm}^{3}$ (DQ715) ligand concentration. The $\mathrm{Zn}(\mathrm{II})-\mathrm{DQ715}$ ratios were $0: 1$, $1: 1,1: 2$ and $1: 4$. The ionic strength was adjusted to $I=0.2 \mathrm{~mol} /$ $\mathrm{dm}^{3}$ with $\mathrm{KCl}$ in each sample. The $\mathrm{pH}$ of the solutions $\left(\mathrm{pH}_{\text {observed }}\right)$ was measured with a pH-sensitive glass electrode (Metrohm 6.0234 .100 ) and an Orion $710 \mathrm{~A} \mathrm{pH}$ meter, calibrated according to the procedure described in the literature [25]). The equilibrium constants and the limiting chemical shifts of the species formed during protonation and $\mathrm{Zn}$ (II)-complexation were calculated by PSEQUAD [26].

\subsection{EPR measurements}

All CW-EPR spectra were recorded with a BRUKER EleXsys E500 spectrometer (microwave frequency $\sim 9.7 \mathrm{GHz}$, microwave power $13 \mathrm{~mW}$, modulation amplitude $5 \mathrm{G}$, modulation frequency $100 \mathrm{kHz}$ ). The isotropic EPR spectra were recorded at room temperature in a circulating titration system. Nine EPR spectra were recorded at $1 \mathrm{mmol} / \mathrm{dm}^{3} \mathrm{CuCl}_{2}$ and $2 \mathrm{mmol} / \mathrm{dm}^{3}$ DQ715 ligand concentration, and six at $2 \mathrm{mmol} / \mathrm{dm}^{3} \mathrm{CuCl}_{2}$ and $2 \mathrm{mmol} / \mathrm{dm}^{3}$ DQ715 ligand concentration, in the $\mathrm{pH}$ range 2-6 and 2-8.5, respectively. At higher $\mathrm{pH}$ values precipitation was detected in both cases. The ionic strength of $0.2 \mathrm{~mol} / \mathrm{dm}^{3}$ were adjusted with

\section{DQ715}<smiles>Cc1c[n+](C)cc(C(=O)O)c1O</smiles>

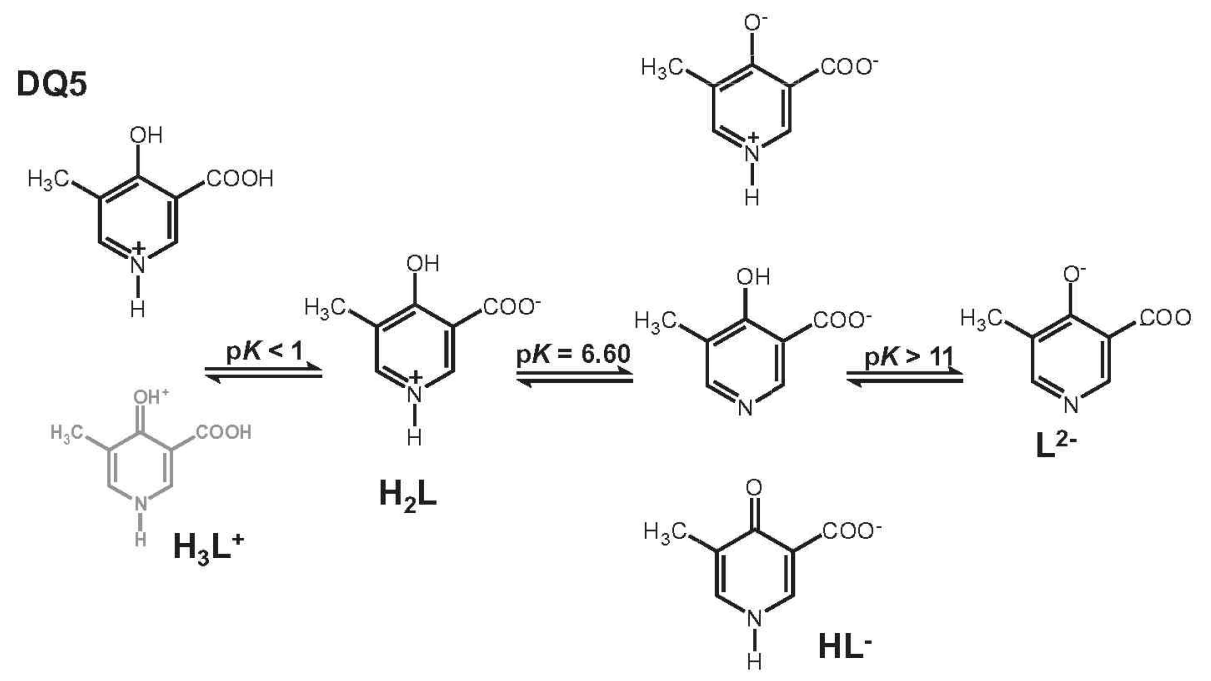

Scheme 2. Deprotonation steps of DQ5 and DQ715. 
$\mathrm{KCl}$. $\mathrm{KOH}$ solution was added to the stock solution to change the $\mathrm{pH}$ which was measured with an Orion $710 \mathrm{~A} \mathrm{pH}$-meter equipped with a Metrohm 6.0234.100 glass elecrode. A Heidolph Pumpdrive 5101 peristaltic pump was used to circulate the solution from the titration pot through a capillary tube into the cavity of the instrument. The titrations were carried out under nitrogen atmosphere. At various $\mathrm{pH}$ values, samples of $0.1 \mathrm{~cm}^{3}$ were taken, and frozen in liquid nitrogen, and the CW-EPR spectra were recorded under the same instrumental conditions as the room-temperature spectra described above.

\subsection{Evaluation of EPR spectra}

The room-temperature EPR spectra were simulated simultaneously by the "two-dimensional" 2D_EPR program [27]. Each component curve was described by the isotropic EPR parameters $g_{0}$, $A_{\mathrm{o}}{ }^{\mathrm{Cu}}$ copper hyperfine coupling, and the relaxation parameters $\alpha$, $\beta, \gamma$ which define the linewidth through the equation $\sigma_{\mathrm{MI}}=\alpha+\beta$ $\mathrm{M}_{\mathrm{l}}+\gamma \mathrm{M}_{\mathrm{l}}{ }^{2}$, where $\mathrm{M}_{\mathrm{I}}$ denotes the magnetic quantum number of copper nucleus. The concentration of the complexes was varied by fitting their formation constants, $\beta\left(\mathrm{M}_{\mathrm{p}} \mathrm{L}_{\mathrm{q}} \mathrm{H}_{\mathrm{r}}\right)$ defined above, in the experimental description of $\mathrm{pH}$-potentiometric studies.

The anisotropic spectra were analysed individually by the EPR program [28], which gives the anisotropic EPR parameters $\left(g_{x}, g_{y}\right.$, $g_{z}, A_{x}{ }^{\mathrm{Cu}}, A_{y}{ }^{\mathrm{Cu}}, A_{z}{ }^{\mathrm{Cu}}$ ) and the orientation dependent linewidth parameters).

For each spectrum, the noise-corrected regression parameter $(R)$ is derived from the average square deviation (SQD) between the experimental and the calculated intensities. For the series of spectra, the fit is characterized by the overall regression coefficient $R$, calculated from the overall average SQD. The details of the statistical analysis were published previously [27]. Since a natural $\mathrm{CuCl}_{2}$ was used for the measurements, all spectra were calculated as the sum of the spectra of ${ }^{63} \mathrm{Cu}$ and ${ }^{65} \mathrm{Cu}$ weighted by their natural abundances. The copper coupling constants and the relaxation parameters were obtained in field units (Gauss $=10^{-4} \mathrm{~T}$ ).

\subsection{Determination of the distribution coefficients}

$D$ values of the both ligands were determined by the traditional shake flask method $[29,30]$ in $n$-octanol/buffered aqueous solution at $\mathrm{pH} 7.4$ (HEPES at $25.0 \pm 0.2^{\circ} \mathrm{C}$. Two parallel experiments were performed for each sample. $D$ of the carrier ligands was calculated as the mean of [Absorbance (original solution)/Absorbance (aqueous phase after separation)-1] obtained in the region of $\lambda_{\max } \pm 10 \mathrm{~nm}$. The partition coeffeicient values $(\log P)$ for the neutral forms of the ligands were calculated by taking into account the appropriate proton dissociation constants.

The partition coefficients of the neuatral forms of the ligands $\left(\log P_{7.40}\right)$, characterising their lipophilicity, were -0.11 for DQ715 and -0.46 for $\mathrm{DQ} 5$. These values represent only moderate lipophilicity.

\subsection{Cell cultures and cytotoxicity assay}

Human Embryonic Kidney 293 (HEK-293) cell line was obtained by ATCC, Rockville, MD. Cells were maintained in the logarithmic phase at $37^{\circ} \mathrm{C}$ in a $5 \%$ carbon dioxide atmosphere using the DMEM medium (Euroclone) containing 10\% fetal calf serum (Euroclone, Milan, Italy), antibiotics ( 50 units $\mathrm{cm}^{-3}$ penicillin and $50 \mu \mathrm{g} \mathrm{cm}^{-3}$ streptomycin) and $2 \mathrm{mmol} / \mathrm{dm}^{3}$ L-glutamine. The growth inhibitory effect toward HEK-293 cell line was evaluated by means of MTT (tetrazolium salt reduction) assay [31]. Briefly, $3 \times 10^{3}$ cells were seeded in 96-well microplates in growth medium $\left(0.1 \mathrm{~cm}^{3}\right)$ and then incubated at $37^{\circ} \mathrm{C}$ in a $5 \%$ carbon dioxide atmosphere. After $24 \mathrm{~h}$, cells were treated with the compound to be stud- ied at the appropriate concentration. Triplicate cultures were established for each treatment. After $24 \mathrm{~h}$, each well was treated with $0.01 \mathrm{~cm}^{3}$ of a $5 \mathrm{mg} \mathrm{cm} \mathrm{cm}^{-3}$ MTT saline solution, and after following $5 \mathrm{~h}$ of incubation, $0.1 \mathrm{~cm}^{3}$ of a sodium dodecylsulfate (SDS) solution in $\mathrm{HCl}\left(0.01 \mathrm{~mol} / \mathrm{dm}^{3}\right)$ were added. After overnight incubation in the dark at $37{ }^{\circ} \mathrm{C}$ in a $5 \%$ carbon dioxide atmosphere, the inhibition of cell growth induced by tested compounds was detected by measuring the absorbance of each well at $570 \mathrm{~nm}$ using a Bio-Rad 680 microplate reader (Milan, Italy). Mean absorbance for each drug dose was expressed as a percentage of the control untreated well absorbance and plotted versus drug concentration. $\mathrm{IC}_{50}$ values represent the drug concentrations that reduced the mean absorbance at $570 \mathrm{~nm}$ to $50 \%$ of those in the untreated control wells.

\section{Results and discussion}

\subsection{Protonation constants}

The acid-base properties of DQ5 and DQ715 were studied by potentiometric and spectroscopic techniques. The protonation constants presented here for these ligands are in good agreement with those reported in previous papers, when the difference in ionic strength is taken into account [15]. The $\mathrm{p} K_{\mathrm{a}}$ values also

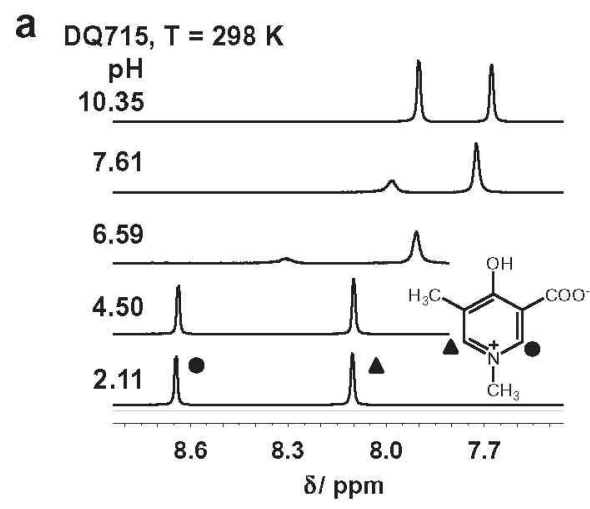

b $D Q 5, T=298 \mathrm{~K}$
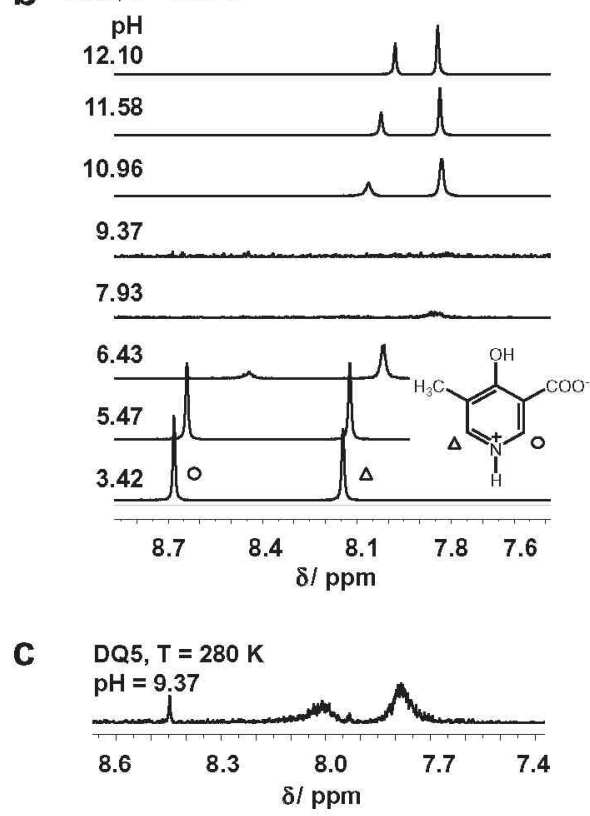

Fig. 1. Low-field region of the ${ }^{1} \mathrm{H}$ NMR spectra of the ligands at the indicated $\mathrm{pH}$ values at $T=298 \mathrm{~K}(\mathrm{a}, \mathrm{b})$ and $T=280 \mathrm{~K}(\mathrm{c})\left(\mathrm{C}_{\mathrm{DQ} 5}=1.1 \times 10^{-3} \mathrm{~mol} / \mathrm{dm}^{3}, c_{\mathrm{DQ} 715}=2\right.$ $\times 10^{-3} \mathrm{~mol} / \mathrm{dm}^{3} I=0.2 \mathrm{~mol} / \mathrm{dm}^{3}(\mathrm{KCl})$ ). 
corresponds to those of related compounds with different ring substituents [15-17,32].

The protonation constants of DQ715, and DQ5 are listed in Table 1 . The significant decrease in acidity of the carboxylic group in the ligands $\left(\log K\left(\mathrm{COO}^{-}\right) \leqslant 1\right)$ can be mainly attributed to the formation of an intramolecular hydrogen-bonding between the $\mathrm{COO}^{-}$and the phenolic $\mathrm{OH}$, which favours the liberation of the first proton [15]. The significantly lower second $\mathrm{p} K_{\mathrm{a}}$ in DQ715 than the $\mathrm{p} K_{\mathrm{a}}$ of the phenolic $\mathrm{OH}$ in phenol or in salicylic acid has presumably due to the possibility of the formation of a chinoid isomeric structure (Scheme 2). The existence of the chinoidic and aromatic isomer forms of $\mathrm{L}^{-}$is supported by ${ }^{1} \mathrm{H}$ NMR measurements (Fig. 1a).

The exclusive formation of $\mathrm{HL}$ is seen at $\mathrm{pH} 2.11$ and 4.50. Increasing the $\mathrm{pH}$ the signals start to broaden and shifted. The shifting can be explained by the deprotonation processes and the broadening may support the assumption that two tautomeric forms exist at these $\mathrm{pH}$ values. The chinoidic and the aromatic forms are in a fast exchange with respect to the ${ }^{1} \mathrm{H}$ NMR time scale resulting in the broadened signals, however, at $\mathrm{pH} 10.35$ the peaks become sharp again suggesting that a single species, the aromatic form is dominating again at this high $\mathrm{pH}$.

An unequivocal assignment of the $\mathrm{p} K_{2}$ and $\mathrm{p} K_{3}$ values of DQ5 is not possible either, because 4-hydroxypyridine derivatives can adopt a chinoid electronic configuration in tautomeric equilibrium with the corresponding aromatic form. In case of DQ5 three $\mathrm{HL}^{-}$ forms can exist (Scheme 2). The similar behavior could also be seen in the spectra (Fig. 1b). The signals start to broaden and shift above $\mathrm{pH} \sim 5.4$, and they practically disappear at 9.37. Probably at this $\mathrm{pH}$ value the three different forms exist simultaneously also in fast exchange. Increasing the $\mathrm{pH}$ the signals become sharp again. At $\mathrm{pH}$ $9.37{ }^{1} \mathrm{H}$ NMR spectrum was recorded at $280 \mathrm{~K}$ too (Fig. 1c) showing that one of the signals $(\delta=8.45 \mathrm{ppm})$ separated and became sharper while the signals of the other two isomers remained broad. This spectrum may also support the coexistence of three forms in the $\mathrm{pH}$ range $6.0-9.7$.

The last $\mathrm{p} K_{\mathrm{a}}$ of $\mathrm{DQ} 5$ could not be accurately measured because it is too high. Therefore, we disregarded the last proton dissociation process and considered $\mathrm{HL}$ as the complex-forming species in the equilibrium $p \mathrm{M}+q \mathrm{HL}+r \mathrm{H}=\mathrm{M}_{p} \mathrm{~L}_{q} \mathrm{H}_{r+q}$ (for simplicity, charges will be generally omitted from the formulae, except in the Tables). In this way, more accurate formation constants were obtained, although their numerical values differ by the value of the last $\mathrm{p} K_{\mathrm{a}}$ from those calculated in the usual way for the equilibrium $p \mathrm{M}+q \mathrm{~L}+r \mathrm{H}=\mathrm{M}_{p} \mathrm{~L}_{q} \mathrm{H}_{r}$.

\section{2. $C u(I I)-D Q 5$ and $C u(I I)-D Q 715$ systems}

The chelating ability of DQ5 and DQ715 for Cu(II) was evaluated on the basis of the cumulative formation constants of their complexes, which were determined by potentiometric, UV-Vis, and (in case of DQ715) by EPR measurements.

The $\mathrm{pH}$-potentiometric titration curves measured at 1:1,1:2 and 1:4 metal ion-to-ligand concentration ratios, normalized to the

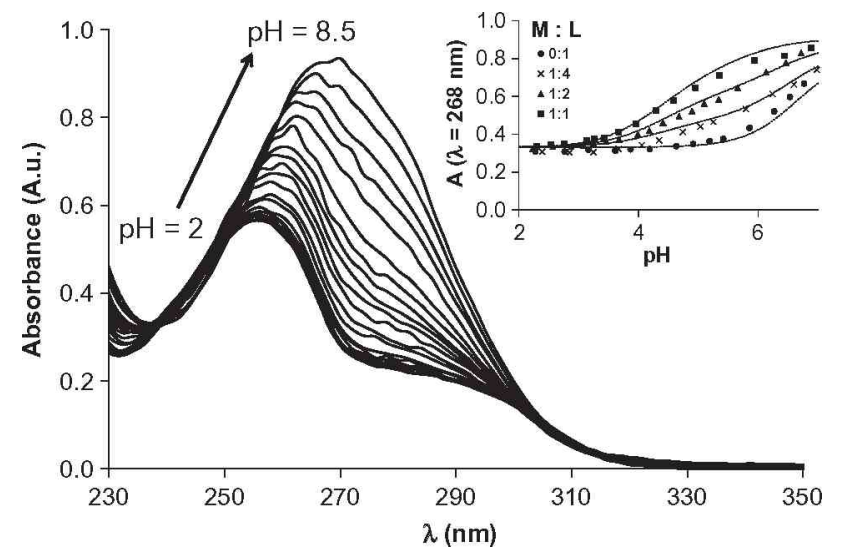

Fig. 3. Spectrophotometric absorbance curves of the Cu(II)-DQ715 system at various $\mathrm{pH}$ values; $c_{\mathrm{Cu}(\mathrm{II})}=4 \times 10^{-5} \mathrm{~mol} / \mathrm{dm}^{3}, c_{\mathrm{DQ} 715}=8 \times 10^{-5} \mathrm{~mol} / \mathrm{dm}^{3}$. The inset shows the change in the absorbance the fitted curves were calculated (with dashed line) at $268 \mathrm{~nm}$ as function of the $\mathrm{pH}\left(I=0.2 \mathrm{~mol} / \mathrm{dm}^{3}(\mathrm{KCl}), T=298 \mathrm{~K}\right)$.
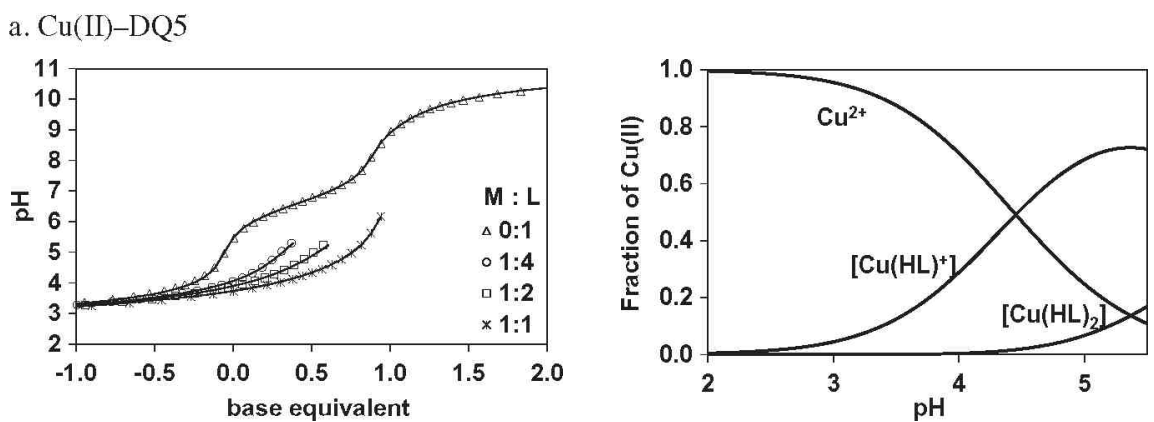

b. $\mathrm{Cu}(\mathrm{II})-\mathrm{DQ} 715$
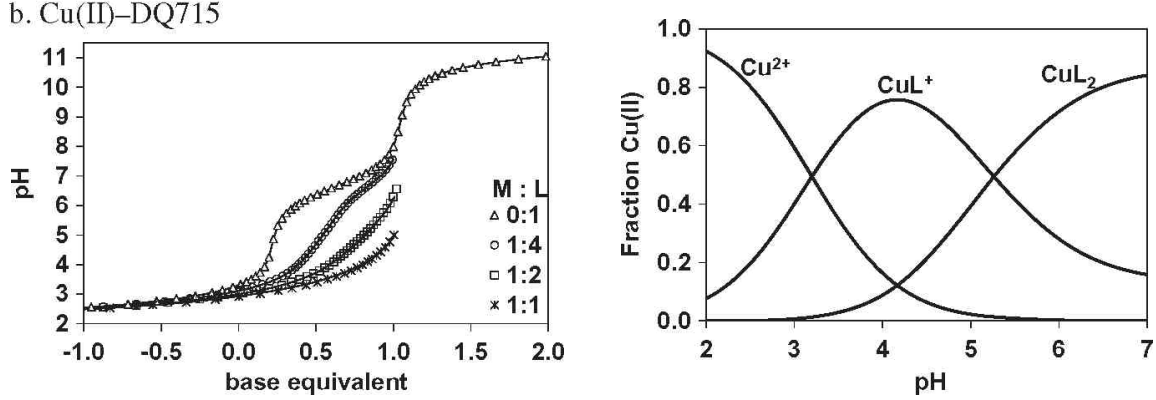

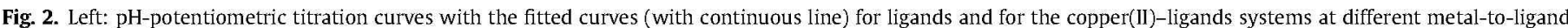

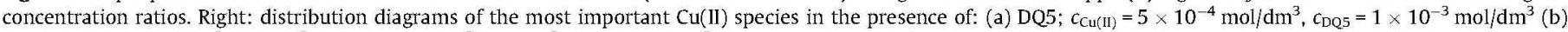
$\mathrm{DQ715} ; c_{\mathrm{Cu}(I)}=1 \times 10^{-3} \mathrm{~mol} / \mathrm{dm}^{3}, c_{\mathrm{DQ} 715}=2 \times 10^{-3} \mathrm{~mol} / \mathrm{dm}^{3}\left(I=0.2 \mathrm{~mol} / \mathrm{dm}^{3}(\mathrm{KCl}), T=298 \mathrm{~K}\right)$. 
ligand concentration, are depicted in Fig. 2. (In all cases, strong acid was added to the solution before titration in order to ensure acidic conditions at the beginning of the measurements. The amount of potassium hydroxide consumed by the strong acid has been subtracted from the total $\mathrm{OH}^{-}$consumption in Fig. 2). In the species distribution curves the predominant species for both ligands are mono complexes. No other species could be assumed to improve the fit of the titration curves; e.g. no tris complex formation in measurable concentration was indicated under the experimental conditions.

The shape of the analogous titration curves in both $\mathrm{Cu}(\mathrm{II})-\mathrm{li}-$ gand systems are similar until $\mathrm{pH} 5$, indicating similar processes in the solution. Complex formation starts at $\mathrm{pH}>3$. After a proton loss from the carboxylic group, in the presence of the metal ion a further deprotonation step is observed on the titration curves. Although potentiometric data do not give any structural information, it is reasonable to assume that the ligands coordinate to the metal ion through the carboxylate oxygen and phenolate (bidentate chelation), and the pyridinic- $\mathrm{N}$ remains protonated in the $\mathrm{Cu}-\mathrm{DQ} 5$ complexes in the $\mathrm{pH}$ range studied. Accordingly, composition of the complex is $\mathrm{Cu}(\mathrm{HL})$, (while in the case of DQ715 as the pyridine- $\mathrm{N}$ is methylated $\mathrm{CuL}$ ). This result is similar to those obtained for the complexes formed by 3-hydroxy-2-pyridinecarboxylic acid and 4-hydroxy-3-pyridinecarboxylic acid with aluminium(III) and iron(III) where the pyridinic-N also remains protonated in the complexes at neutral $\mathrm{pH}$ [18].

The sharp break on the titration curve at ligand excess indicates that precipitation occurs at $\mathrm{pH} \approx 5$ in the $\mathrm{Cu}(\mathrm{II})-\mathrm{DQ} 5$ solutions. Although the precipitate was not accurately analysed, presumably it is the neutral bis complex, as when the complex was filtered off and redissolved in dilute $\mathrm{HCl}$ acid, significant amount of the ligand could be detected in the solution spectrophotometrically. It should also be mentioned that in the samples with ligand excess precipitation started at the same metal ion concentration when the concentration of $\mathrm{Cu}(\mathrm{HL})_{2}$ reached the value of about $2.7 \times 10^{-4} \mathrm{~mol} / \mathrm{dm}^{3}$, which is the concentration of the saturated solution of the complex (as calculated from the stability constants listed in Table 1).

Note that in the case of DQ5 the monoprotonated species while in the case of DQ715 the fully deprotonated catecholic $L$ is the complex forming ligand form.

The limited solubility of the ligands in water allowed to carry out the pH-potentiometric titrations at a maximum of $\sim 2 \mathrm{mmol} /$ $\mathrm{dm}^{3}$ DQ715 and $\sim 1 \mathrm{mmol} / \mathrm{dm}^{3}$ DQ5 concentrations, and despite the low solubility of the bis complex of DQ5, interpretation of the potentiometric data leaves little doubt on the speciation model. UV-Vis spectrophotometric measurements were performed to confirm the pH-potentiometric speciation result. Absorbance curves of the $\mathrm{Cu}(\mathrm{II})-\mathrm{DQ} 715$ system are shown in Fig. 3.

Fig. 3 shows the pH-dependent UV-Vis spectra of Cu(II)-DQ715 system and the change in the absorbance at $264 \mathrm{~nm}$ as function of the $\mathrm{pH}$ at various metal-to-ligand ratios. Spectra are very similar to those obtained for Cu(II)-DQ5 system (not shown). For DQ715 at $\mathrm{pH} \mathrm{2,} \mathrm{the} \mathrm{main} \mathrm{peak} \mathrm{at} 252 \mathrm{~nm}$ is due to $\pi \rightarrow \pi^{*}$ transition of the pyridinic ring, and by increasing the $\mathrm{pH}$ the deprotonation causes a bathochromic shift till around $270 \mathrm{~nm}$. The presence of $\mathrm{Cu}$ (II) does not modify strongly the UV-Vis spectra of the ligands. Only small modifications in the intensity and in the wavelength occur as a function of $\mathrm{pH}$. The complex formation was evidenced by monitoring the absorption change in the wavelength range 230 $350 \mathrm{~nm}$. At in this low concentration no other absorption band disturbed the detected spectra. The stability constants of the different complexes were determined from the $\mathrm{pH}$-dependent spectra. For both ligands, the UV-Vis spectra allowed the detection of two complexes, $\mathrm{CuL}$ and $\mathrm{CuL}_{2}$ for DQ715, and $\mathrm{CuLH}$ and $\mathrm{CuL}_{2} \mathrm{H}_{2}$ for DQ5 and the calculation of their stability constants. The UV-Vis $\log \beta$ values agree well with those determined potentiometrically (see Table 1), thus confirming the lack of the formation of any other species in these metal-ligand systems.

EPR measurements were also carried out for Cu(II)-DQ715 solutions in order to confirm the $\mathrm{pH}$-metric and spectrophotometric results and to obtain structural information on the complexes. The isotropic and anisotropic EPR spectra could be explained by taking into account the formation of $1: 1$ and $1: 2$ complexes, beside the copper(II)aqua complex (Fig. 4). The slight decrease of the g values in the mono complex as compared with the $g$ values of the aqua complex indicates metal ion coordination by weak oxygen donors presumably $\left[\mathrm{COO}^{-}, \mathrm{O}^{-}\right]$binding mode. Further decrease in $\mathrm{g}$ and increase in $A$ values occur in the bis complex indicating $2 \times\left[\mathrm{COO}^{-}, \mathrm{O}^{-}\right]$coordination. The coordination of the two ligands in cis-trans geometric isomers could not be distinguished, possibly because of their very close EPR parameters. Determination of both isotropic and anisotropic EPR data of complexes $\mathrm{CuL}$ and $\mathrm{CuL}_{2}$ allowed to predict the sign of their anisotropic copper hyperfine couplings $\left(A_{x}\right.$ and $\left.A_{y}\right)$ (The determination of signs otherwise is a difficult problem and re-
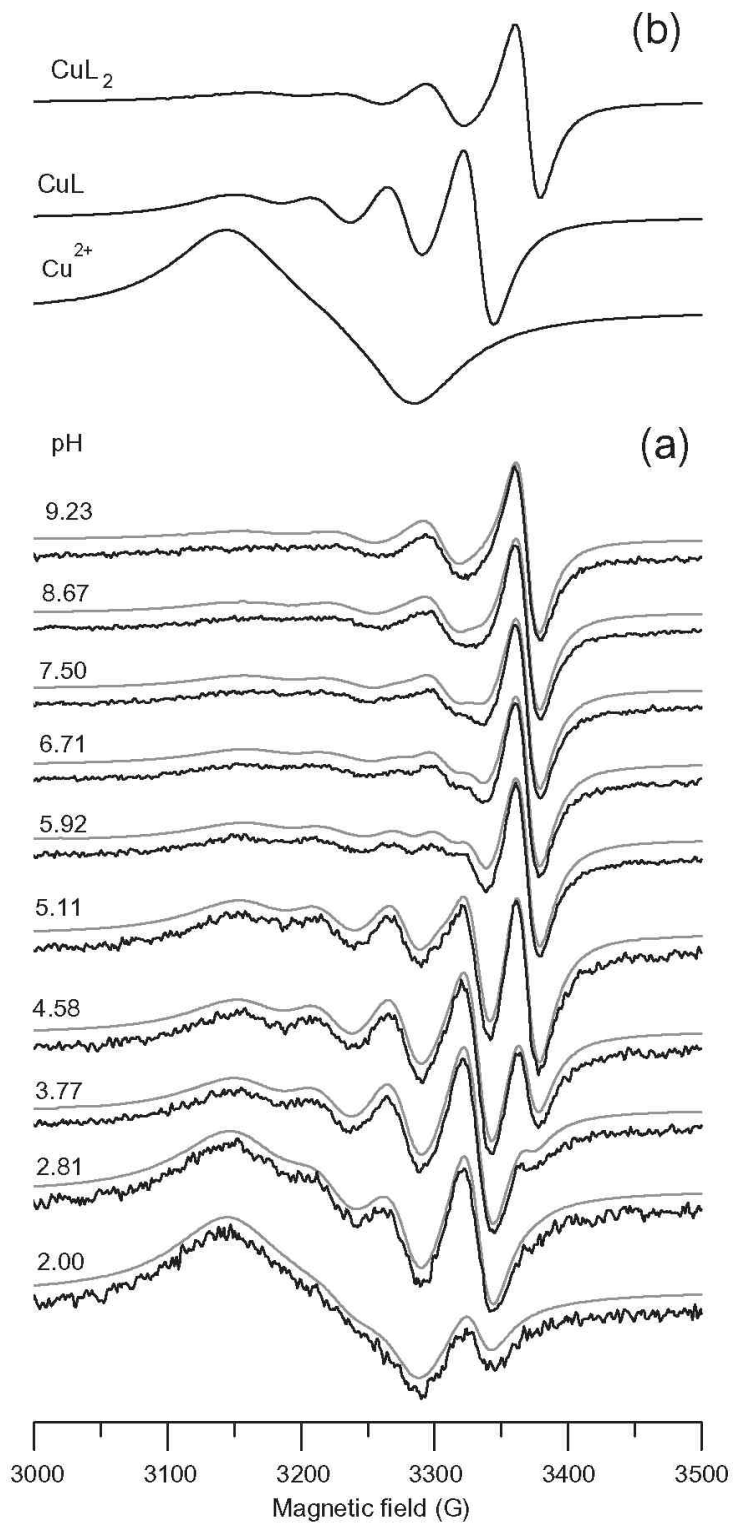

Fig. 4. (a) $\mathrm{pH}$ dependent series of experimental (black) and simulated (gray) EPR spectra $\left(c_{\mathrm{DQ} 715}=2 \times 10^{-3} \mathrm{~mol} / \mathrm{dm}^{3}, c_{\mathrm{Cu}}=1 \times 10^{-3} \mathrm{~mol} / \mathrm{dm}^{3}, I=0.2 \mathrm{~mol} / \mathrm{dm}^{3}(\mathrm{KCl})\right.$ $T=298 \mathrm{~K}$ ), and (b) calculated component EPR spectra obtained by the "twodimensional" simulation. 
quires ENDOR or pulsed EPR measurements. The positive or negative sign of these two values can change easily because of the similar magnitudes but varying signs of the contributed Fermi contact term, spin-dipolar coupling and the spin-orbit interaction). In this study the measured isotropic hyperfine values have been compared with those of the averaged values calculated by the equation $A_{0}=\left(A_{x}+-\right.$ $\left.A_{y}+A_{z}\right) / 3$ using different signs for $A_{\mathrm{x}}$ and $A_{y}$. (Negative sign for $A_{z}$ is known for copper(II) complexes with elongated octahedral geometry). The signs giving the best accordance are shown in Table 2 . The good agreement between the measured and calculated values presume also that the complex structure formed in solution is kept upon freezing. Comparing the EPR parameters of $\mathrm{CuL}\left(g_{0}=2.166\right.$ and $A_{o}=53 \mathrm{G}$ ) with those of copper(II)-fluorosalicylic acid analogoues $\left(g_{o}=\sim 2.179-2.186\right.$ and $A_{o}=\sim 35-38 \mathrm{G}$ ) [33], we can conclude that much higher $g_{0}$ values and lower $A_{0}$ values could be detected than for the different fluorosalicylic complexes. This indicates a significantly higher ligand field for DQ715 as compared with fluorosalicylic acid, owing to the positive inductive effect of the pyridinic nitrogen in contrast with the negative inductive effect of the fluorine. This agrees with the higher formation constants and the predominant formation of CuL in case of DQ715.

The formation constants and EPR parameters for the various $\mathrm{Cu}$ (II) complexes are summarized in Tables 1 and 2 .

The $\mathrm{Cu}(\mathrm{II})$ binding ability of both ligands are in the several hundreds $\mathrm{nM}$ range ( $310 \mathrm{nM}$ for DQ5 and 510 for DQ715). These values means moderate binding ability are significantly lower than that of salicylic acid (13.4 $\mu \mathrm{M})$ [34] but much higher than that of deferiprone (8.81 nM) [35]. This means that the electronic effect of the pyridinic- $\mathrm{N}$ (as compared to the aromatic benzene ring) in the ring increases the donor strength of the $\mathrm{O}$ atoms, but the electronic structure of the pyridinone ring offer an extra donor strength to the $O$ atoms.

\section{3. $Z n(I I)-D Q 5$ and $Z n(I I)-D Q 715$ systems}

The complex formation constants of $\mathrm{Zn}$ (II)-DQ715 and $\mathrm{Zn}$ (II)DQ5 systems are listed in Table 1. In agreement with the expectations only mononuclear complexes are formed in both systems and the order of magnitude of the complex stability obtained in this study is similar with the earlier findings reported for the $\mathrm{Zn}(\mathrm{II})-2$-hydroxynicotinic acid system [20]. This suggests the same binding mode in the complexes formed in these systems, i.e. a bidentate coordination of the carboxylate and hydroxyl groups. Accordingly, the pyridinic- $\mathrm{N}$ remains protonated. Representative species-distribution diagrams for typical $\mathrm{Zn}$ (II)-DQ715 and $\mathrm{Zn}$ (II)-DQ5 systems are depicted in Fig. 5. The metal complex speciation in these systems do not differ considerably from each other. It can be seen that the complexation begins at pH 3.5 with the monocomplex. The bis complex becomes predominant above $\mathrm{pH}$ 6. No evidence was found for the presence of any tris-complex in the experimental conditions applied. For both $\mathrm{Zn}$ (II)-DQ715 and $\mathrm{Zn}$ (II)-DQ5 systems, the $\mathrm{pH}$ interval examined in the potentiometric and ${ }^{1} \mathrm{H}$ NMR measurements was limited because of early precipitation of solid compounds. Precipitation occurred at $\mathrm{pH} \approx 8$ and the appearrance of the precipitate suggest that it is $\mathrm{Zn}(\mathrm{OH})_{2}$.

To support the potentiometric data, ${ }^{1} \mathrm{H}$ NMR spectra were recorded in the presence of DQ715 at various $\mathrm{pH}$ values in $\mathrm{H}_{2} \mathrm{O}$ / $\mathrm{D}_{2} \mathrm{O}$ solution at $1: 0,1: 1,1: 2$, and $1: 4$ metal-to-ligand ratios. Due to the formation of the kinetically labile $\mathrm{Zn}$ (II) complexes, the position but not the number and multiplicity of the NMR signals, change as a function of $\mathrm{pH}$. Stability constants of the complexes were calculated from the extent of shifts of the signals by the PSEQUAD computer program. Results are very similar to those obtained from pH-potentiometry (Table 1). Fig. 6 shows the measured and calculated chemical shifts of the $\mathrm{N}-\mathrm{CH}-\mathrm{C}-\mathrm{COO}$ as a function of $\mathrm{pH}$.

The Zn(II)-ligand complex formation was monitored by UV-Vis spectrophotometric measurements too, but suitable UV-Vis spectra could not be obtained because of the slight changes in the absorption due to the low level of complexes formation with both DQ5 and DQ715.

Table 2

EPR parameters of components formed in CU(II)-DQ715 system.

\begin{tabular}{|c|c|c|c|c|c|c|c|c|}
\hline & \multicolumn{2}{|c|}{ Isotropic EPR data ${ }^{a}$} & \multicolumn{4}{|c|}{ Anisotropic EPR data ${ }^{b}$} & \multicolumn{2}{|c|}{ Calculated isotropic EPR data } \\
\hline & $g_{0}$ & $\left|A_{0}\right| / G$ & $g_{\perp} g_{x} g_{y}$ & $\begin{array}{l}g_{\|\|} \| \\
g_{z}\end{array}$ & $A_{\perp} / G A_{x}, A_{y} / G^{c}$ & $A_{\|\|} / G A_{z} / G$ & $g_{\text {orcalc }}$ & $\left|A_{\text {orcald }}\right|^{\mathrm{d}} / G$ \\
\hline $\mathrm{Cu}^{2+}$ & $2.194(1)$ & $34.6(6)$ & 2.079 & 2.412 & 8.0 & -116.0 & 2.190 & 37.5 \\
\hline CuL & $2.166(1)$ & $53.1(1)$ & $2.069,2.069$ & 2.347 & $12.0,-12.0$ & -147.0 & 2.161 & 53.2 \\
\hline $\mathrm{CuL}_{2}$ & $2.149(1)$ & $60.8(1)$ & $2.066,2.059$ & 2.329 & $-8.1,-15.9$ & -150.4 & 2.151 & 62.0 \\
\hline
\end{tabular}

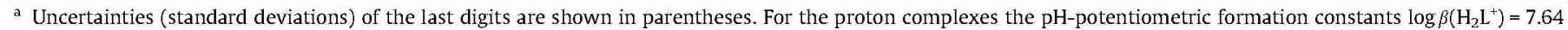
and $\log \beta(\mathrm{HL})=6.64$ were used in the EPR analysis.

$\mathrm{b}$ The experimental errors were \pm 0.001 for $g_{x}$ and $g_{y}$ and \pm 0.0005 for $g_{z} \pm 2 \mathrm{G}$ for $A_{x}$ and $A_{y}$ and $\pm 1 G$ for $A_{z}$.

c The signs of the experimental values were derived from a comparison of $A_{0 \text {,calc }}$ with the experimental $A_{0}$.

${ }^{d}\left|A_{0, \text { calc }}\right|=\left|\left(A_{\mathrm{x}}+A_{\mathrm{y}}+A_{\mathrm{z}}\right) / 3\right|$.
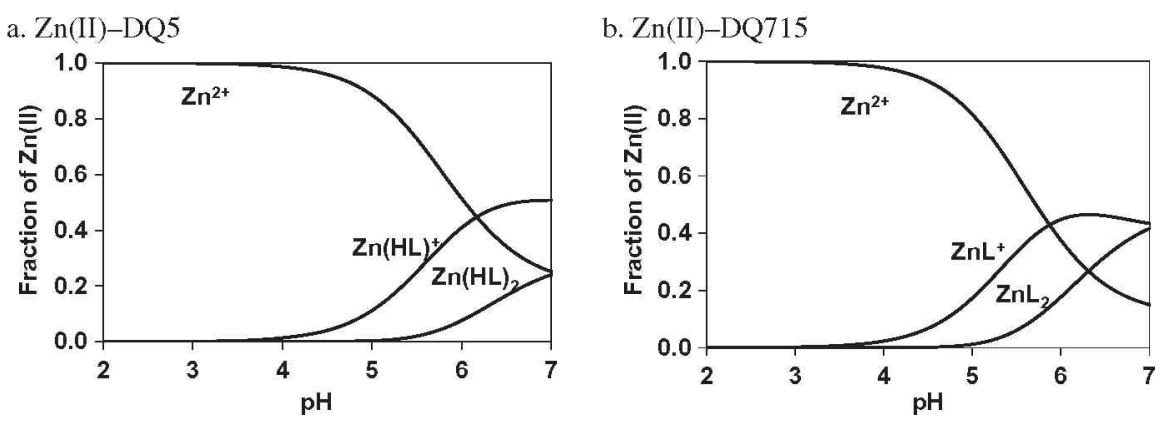

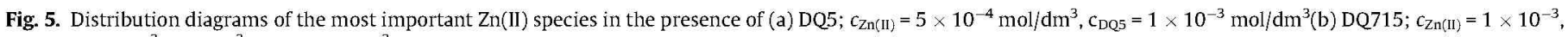
$C_{\mathrm{DQ} 715}=2 \times 10^{-3} \mathrm{~mol} / \mathrm{dm}^{3}\left(I=0.2 \mathrm{~mol} / \mathrm{dm}^{3}(\mathrm{KCl}) T=298 \mathrm{~K}\right)$. 


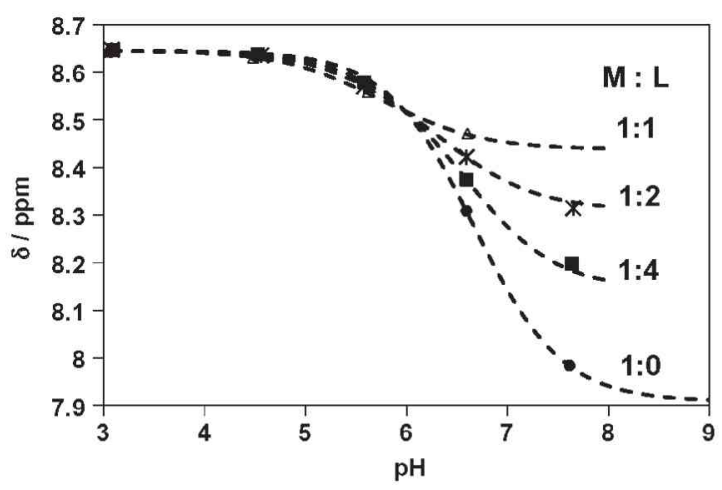

Fig. 6. Calculated and experimental ${ }^{1} \mathrm{H}$ NMR shifts of the of $\mathrm{N}-\mathrm{CH}-\mathrm{C}-\mathrm{COO}$ hydrogen of DQ715 as a function of the pH in Zn(II)-DQ715 system $\left(C_{\mathrm{DQ} 715}=2 \times 10^{-3} \mathrm{~mol} /\right.$ $\left.\mathrm{dm}^{3} I=0.2 \mathrm{M}(\mathrm{KCl}) T=298 \mathrm{~K}\right)$.

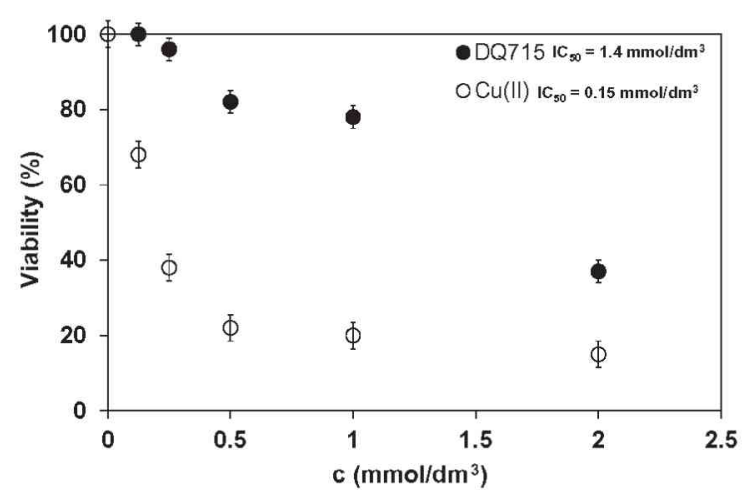

Fig. 7. Cytotoxicity profile of $\mathrm{CuCl}_{2}$ and DQ715. HEK-293 cells were treated for $24 \mathrm{~h}$ with increasing concentrations of $\mathrm{CuCl}_{2}(\bullet)$ or DQ715 (O). Cytotoxicity was evaluated by the MTT test. $\mathrm{IC}_{50}$ values were calculated by four parameter logistic model $(P<0.05)$. Values are shown as the means $( \pm S D)$ of five independent experiments.

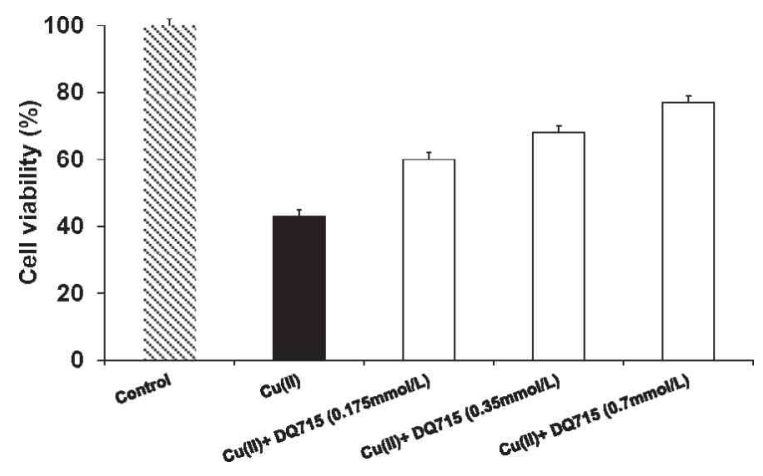

Fig. 8. Effect of $\mathrm{Cu}(\mathrm{II})$ and DQ715 combined treatment. HEK-293 cells were treated for $24 \mathrm{~h}$ with $0.15 \mathrm{mmol} / \mathrm{dm}^{3}$ of $\mathrm{CuCl}_{2}$ and then washed twice with PBS, and reincubated with fresh complete medium (black) or medium added with increasing concentration of DQ715 (white), for further $24 \mathrm{~h}$ before MTT determination. Values are shown as the means $( \pm S D$ ) of five independent experiments.

\subsection{Cytotoxicity studies}

HEK-293 human embryonic kidney cells were tested for their sensitivity to $\mathrm{Cu}(\mathrm{II})\left(\right.$ as $\mathrm{CuCl}_{2}$ )-chloride and DQ715. Cells were treated for $24 \mathrm{~h}$ with increasing concentrations of $\mathrm{CuCl}_{2}$ and DQ715, and cell viability was determined using the MTT test. Results are reported in Fig. 7.
As previously described [15], DQ715 proved to be hardly effective in decreasing cell viability, with an $\mathrm{IC}_{50}$ value of $1.4 \mathrm{mmol} /$ $\mathrm{dm}^{3}$. Conversely, $\mathrm{IC}_{50}$ calculated with $\mathrm{CuCl}_{2}$ was $0.15 \mathrm{mmol} / \mathrm{dm}^{3}$.

In order to study the effect of DQ715 in Cu(II) overload, HEK293 cells were pre-treated with $0.15 \mathrm{mmol} / \mathrm{dm}^{3} \mathrm{CuCl}_{2}$ for $24 \mathrm{~h}$ and further challenged with increasing concentrations $(0.0$ $0.7 \mathrm{mmol} / \mathrm{dm}^{3}$ ) of DQ715 for additional $24 \mathrm{~h}$ treatment. Fig. 8 shows the results obtained with MTT test. Co-treatment of HEK293 cell with DQ715 and $\mathrm{CuCl}_{2}$ determined a DQ715 dose-dependent decrease of copper salt cytotoxicity, supporting the hypothesis that DQ715 can reduce the copper induced antiproliferative effect. Unfortunately DQ5 could not be studied because of the lower solubility of the compound.

\section{Conclusions}

The chemical interactions between the metals $\mathrm{Zn}$ (II) and $\mathrm{Cu}$ (II) and the ligands DQ715 and DQ5 have been investigated. The speciations are very similar, as only mononuclear mono and bis complexes are detected in solution. The two ligands have a similar metal binding ability towards $\mathrm{Zn}$ (II) and $\mathrm{Cu}(\mathrm{II})$. They are typical hard ligands and therefore form weaker complexes with $\mathrm{Zn}(\mathrm{II})$ and $\mathrm{Cu}(\mathrm{II})$ than with $\mathrm{Fe}(\mathrm{III})$ and $\mathrm{Al}(\mathrm{III})$ [15]. DQ715 forms slightly weaker complexes than DQ5 due to the N-methyl substitution of the pyridine ring which increases the hard character of the chelator. To compare the metal binding strength of the ligands at physiological $\mathrm{pH}$, the $K_{\mathrm{D}}$ values have been calculated for the complexes at $\mathrm{pH}$ 7.4. The values obtained are in the $\mathrm{mM}$ range for the $\mathrm{Zn}(\mathrm{II})$ complexes, i.e.the $\mathrm{Zn}$ (II) binding affinity of both ligands is rather low. Therefore the ligands can not have a positive influence on the zinc homeostasis, i.e. DQ5 and DQ715 are expected to hardly restore or remove only a small amount of zinc. However, this low affinity may be important if DQ5 and DQ715 is going to be used as Fe or Al chelators, because zinc deficiency problems are sometimes experienced in hard metal chelation therapy (e.g. for deferiprone $[18,19]$ ). DQ5 and DQ715 are expected to cause no zinc deficiency problem.

The affinity of the ligands for $\mathrm{Cu}(\mathrm{II})$ is higher than for $\mathrm{Zn}(\mathrm{II})$. The $K_{\mathrm{D}}$ values are several hundred of nanomolar for both ligands. The optimal $K_{\mathrm{D}}$ values reported in the literature for $\mathrm{Cu}(A \beta)$ range from $10 \mathrm{pM}$ to $100 \mathrm{nM}$ [8]. In any case it appears that DQ5 and DQ715 cannot retrieve $\mathrm{Cu}(\mathrm{II})$ from the amyloid aggregates. However, the strength of the interactions with $\mathrm{Cu}(\mathrm{II}) \mathrm{can}$ be enough to bind the copper(II) excess in the cells and protect them from the copper-induced redox processes, which would generate ROS species. This protection might explain why the $\mathrm{Cu}(\mathrm{II})$-treated cells showed higher viability in the presence of DQ715. This protecting effect has been evaluated also in the presence of Fe(III), and in that case the enhanced effect was attributed to metal chelation [15]. The acute and chronic $\mathrm{Cu}(\mathrm{II})$ toxicity can result in $\mathrm{Cu}$ (II)-induced oxidative damage that has been implicated in disorders associated with abnormal copper metabolism, liver disease and severe neurological defects. Therefore, although the ligand is not a suitable chelator for $\mathrm{Cu}$ (II) to remove this ion from the beta-amyloid proteins, it appears suitable to protect the cells in some extent from the Fe(III) and $\mathrm{Cu}$ (II) related oxidative stress, which may be involved in neurodegenerative disorders, like Alzheimer's disease.

\section{Acknowledgements}

This work was supported by the Hungarian Research Fund (OTKA K77833), and TÂMOP-4.2.2.A-11/1/KONV-2012-0052, supported by the European Union, and it was co-financed by the European Regional Fund and by the Italian-Hungarian CNR-HAS Bilateral Research Program "Venzo-Kiss". This research was real- 
ized in the frames of TÂMOP 4.2.4. A/2-11-1-2012-0001 "National Excellence Program - Elaborating and operating an inland student and researcher personal support system" The project was subsidized by the European Union and co-financed by the European Social Fund. T. Jakusch gratefully acknowledges the financial support of J. Bolyai research fellowship.

\section{References}

[1] E. Gaggelli, H. Kozłowski, D. Valensin, G. Valensin, Chem. Rev. 106 (1995) (2006) 1995.

[2] A.I. Bush, Trends Neurosci. 26 (2003) 207.

[3] G.J. Brewer, J. Trace Elem, Med. Bio. 26 (2012) 89.

[4] A.R. White, G. Multhaup, D. Galatis, W.J. McKinstry, M.W. Parker, R. Pipkorn, K. Beyreuther, C.L. Masters, R. Cappai, J. Neurosci. 22 (2002) 365.

[5] P.M. Doraiswamy, A.E. Finefrock, Lancet Neurol. 3 (2004) 431.

[6] J. Lu, D.M. Wu, Y.L. Zheng, D.X. Sun, B. Hu, Q. Shan, Z.F. Zhang, S.H. Fan, Behavior, and Immunity 23 (2009) 193.

[7] R.A. Cherny, J.T. Legg, C.A. McLean, J. Biol. Chem. 274 (1999) 23223.

[8] P. Faller, C. Hureau, Dalton Trans. (2009) 1080.

[9] M.F. Ahmad, D. Singh, A. Taiyab, T. Ramakrishna, B. Raman, C.M. Rao, J. Mol. Biol. 382 (2008) 812.

[10] M. Raju, P. Santhoshkumar, T.M. Henzl, K.K. Sharma, Free Radical Biol. Med. 50 (2011) 1429

[11] M.A. Lovell, J.D. Robertson, W.J. Teesdale, J.L. Campbell, W.R. Markesbery, J. Neurol. Sci. 158 (1998) 47.

[12] H. Kozlowski, M. Luczkowski, M. Remelli, D. Valensin, Coord. Chem. Rev. 256 (2012) 2129.

[13] D.E. Green, M.L. Bowen, L.E. Scott, T. Storr, M. Merkel, K. Böhmerle, K.H. Thompson, B.O. Patrick, H.J. Schugar, Dalton Trans. 39 (2010) 1604.

[14] M.R. Jones, E.L. Service, J.R. Thompson, M.C.P. Wang, I.J. Kimsey, A.S. DeToma, A. Ramamamoorthy, M.H. Lim, T. Storr, Metallomics 4 (2012) 910.
[15] A. Dean, É. Sija, É. Zsigó, M.G. Ferlin, D. Marton, V. Gandin, C. Marzano, P. Pastore, D. Badocco, A. Venzoe, R. Bertani, T. Kiss, V. Di Marco, Eur. J. Inorg. Chem. 8 (2013) 1310.

[16] E. Sija, A. Dean, T. Jakusch, V.B. Di Marco, A. Venzo, T. Kiss, Monatsh. Chem. 142 (2011) 399.

[17] A. Dean, M.G. Ferlin, P. Brun, I. Castagliuolo, R.A. Yokel, A. Venzo, G.G. Bombi, V.B. Di Marco, Inorg. Chim. Acta 373 (2011) 179.

[18] V.B. Di Marco, R.A. Yokel, M.G. Ferlin, A. Tapparo, G.G. Bombi, Eur. J. Inorg. Chem. (2002) 2648.

[19] V.B. Di Marco, A. Tapparo, G.G. Bombi, Anal. Chim. 89 (1999) 535.

[20] V.B. Di Marco, A. Tapparo, A. Dolmella, G.G. Bombi, Inorg. Chim. Acta 357 (2004) 135.

[21] G.J. Kontoghiorghes, Toxicol. Lett. 80 (1995) 1.

[22] G.J. Kontoghiorghes, M.B. Agarwal, R.W. Grady, A. Koinagou, J.J. Marx, Lancet $356(2000) 428$.

[23] P. Gans, A. Sabatini, A. Vacca, J. Chem. Soc., Dalton Trans. (1985) 1195.

[24] G. Gran, Acta Chem. Scand. 4 (1950) 559.

[25] H.M. Irving, M.G. Miles, L.D. Petit, Anal. Chim. Acta 38 (1967) 475.

[26] L. Zékány, I. Nagypâl, D.L. Leggett (Eds.), Computational Methods for the Determination of Stability Constants, Plenum Press, New York, 1985, 291.

[27] A. Rockenbauer, T. Szabó-Plánka, J. Am. Chem. Soc. 123 (2001) 7646.

[28] A. Rockenbauer, L. Korecz, Appl. Magn. Reson. 10 (1996) 29.

[29] A. Avdeef, B. Testa, Cell. Mol. Life Sci. 59 (2002) 1681.

[30] S.K. Poole, C.F. Poole, J. Chromatogr. B 797 (2003) 3.

[31] M.C. Alley, D.A. Scudiero, A. Monks, M.L. Hursey, M.J. Czerwinski, D.L. Fine, B.]. Abbott, J.G. Mayo, R.H. Shoemaker, M.R. Boyd, Cancer Res. 48 (1988) 589

[32] V.B. Di Marco, A. Dean, R.A. Yokel, H. Li, G.G. Bombi, Polyhedron 26 (2007) 3227.

[33] T. Szabó-Plánka, B. Gyurcsik, I. Pálinkó, N.V. Nagy, A. Rockenbauer, R. Š́poš, J. Šima, M. Melník, J. Inorg. Biochem. 105 (2011) 75.

[34] A.E. Martell, R.M. Smith, Critical Stability Constants, vol. 2, Plenum, New York, 1975.

[35] V.M. Nurchia, G. Crisponia, T. Pivettaa, M. Donatonib, M. Remellib, J. Inorg. Biochem. 102 (2008) 684. 